\title{
Quantitative Detection of raw sheep in Meat Products by a TaqMan Real-Time PCR Assay
}

\author{
Xu Qiong ${ }^{\text {la }}$, Gu Wenjia ${ }^{1 \mathrm{~b}}$, Zhang Yinan ${ }^{\text {lc }}$, Zhang Qingping ${ }^{1 \mathrm{~d}}$, Tao Fei ${ }^{2 \mathrm{e}}$, Hu Xuelian $^{1 \mathrm{f}}$, Zhao Yan ${ }^{1 \mathrm{~g}}$, Duan \\ Wenfeng $^{\text {lh }}$, Qu Qinfen ${ }^{1 *}$ \\ ${ }^{1}$ Shanghai Institute of Quality Inspection and Technical Research, Shanghai, China \\ ${ }^{2}$ Shanghai Jiao Tong University, Shanghai, China \\ axuqiong@sqi.org.cn; ${ }^{\mathrm{a}}$ guwj@sqi.org.cn; ${ }^{\mathrm{c}}$ zhangyn@sqi.org.cn; ${ }^{\mathrm{d}}$ zhangqp@sqi.org.cn; \\ etaofei@sjtu.edu.cn; ${ }^{f}$ huxl@sqi.org.cn; ${ }^{\mathrm{g}}$ zhaoyan@sqi.org.cn; ${ }^{\mathrm{h}}$ duanwf@sqi.org.cn; ${ }^{\mathrm{i}}$ quqf@sqi.org.cn \\ * To whom correspondence should be addressed.
}

\begin{abstract}
In the present work, we propose a normalised real-time quantitative PCR assay to determine the sheep content in raw meat. For the development of the method, the mixtures meats contain known amounts of sheep meat in pork from $20 \%$ to $100 \%$ can be successfully in-house validated by a normalised calibration model with high linear correlation $\left(R^{2}=0.994\right)$ and PCR efficiency $(E=77 \%)$. The method also showed that the limit of detection of sheep in sheep-pork mixtures was $0.8 \% \quad(W / W)$. Thus, this methodology could serve as a fast and sensitive method for quantitative detection of sheep for meat species verification, avoiding fraudulent practices.
\end{abstract}

Keywords-real-time PCR; quantitative detection; raw; Sheep; adulteration

\section{INTRODUCTION}

Transparency in meat speciation is an ever increasing demand and is essential for the protection of consumers'heath, religious credence and hard earned wealth $^{[1,2]}$. Food manufacturers are not only responsible for the safety but also for the authenticity of their products. Since economically advantageous adulteration is a permanent temptation for producers the authorities have to face recurring violation of legal regulations. Recently the detection of horsemeat in a number of processed beef products across Europe led to a series of product recalls. Similar incidents had been occurred in the Chinese market: Fox were posing as donkey meat sold in supermarkets was exposed by Shandong Province Exit Inspection and Quarantine in 2013. Such an event was not the case, making fake sheep meat with a fox, fake dog meat, ham were not uncommon.

At present, A number of analytical analysis methods have been proposed for the verification of the origin of animal products in order to guarantee its traceability, such as electronic nose coupled to gas chromatography-mass spectrometry $^{[3]}$, electrophoretic, chromatographic ${ }^{[4]}$, immunological techniques ${ }^{[5]}$, Fourier transform infrared spectroscopy ${ }^{[6]}$, SYBR green real-time $\mathrm{PCR}^{[7]}$ and TaqMan probe realtime $\mathrm{PCR}^{[8]}$.

Among these methods, TaqMan real-time PCR assays combined with species-specific primers and TaqMan probe are particularly promising because in addition to specific primers, additional species-screening is provided through the specifically-designed TaqMan probe, significantly enhancing the specificity and reliability of the assay ${ }^{[9]}$.

In this work, a TaqMan real-time PCR approach is proposed as a simple, fast, sensitive and reliable method for sheep meat detection and quantification. The method was validated using blind mixtures applied to quantify the presence of sheep meat in sheep-pork meat mixtures available commercially.

\section{MATERIALS AND METHODS}

\section{A. Samples}

Reference samples were prepared in the laboratory with sheep and pork muscles from a local retail market. Immediately after purchase, both meats were cut and the outside portions rejected. The samples were then minced separately and reference binary mixtures containing $100 \%$, $80 \%, 60 \%, 40 \%$ and $20 \%(\mathrm{~W} / \mathrm{W})$ of sheep in pork meat were prepared to a final weight of $10 \mathrm{~g}$.

To validate the methodology, blind validation mixtures containing $79.89 \%, 48.32 \%, 31.74 \%$ and $21.30 \%(\mathrm{w} / \mathrm{w})$ of sheep meat in pork-sheep mixture. To avoid contaminations, all samples and mixtures were minced and homogenised separately in a knife mill using different knives and different blender containers, previously treated with DNA decontaminator solution.

All samples were stored at $-20^{\circ} \mathrm{C}$ to avoid enzymatic degradation of the DNA before the extraction procedure.

\section{B. DNA extraction}

DNA was extracted using the CTAB method described by Barbara Druml ${ }^{[10]}$ with minor modifications. Briefly, $15 \mathrm{~mL}$ CTAB extraction buffer $(2 \%(\mathrm{w} / \mathrm{v}) \mathrm{CTAB}$, $0.02 \mathrm{M}$ EDTA, $0.1 \mathrm{M}$ Tris, $1.4 \mathrm{M}$ sodium chloride, adjusted to pH8.0 with $4 \mathrm{M}$ hydrochloric acid, autoclaved) and $10 \mu \mathrm{L}$ proteinase $\mathrm{K}$ solution were added to $1 \mathrm{~g}$ food meat mixture and incubated at $56^{\circ} \mathrm{C}$ under shaking in an incubator (SW22 Julabo ) overnight.

After centrifugation at $5000 \mathrm{~g}$ (Centrifuge $5415 \mathrm{R}$, Eppendorff) for $5 \mathrm{~min}, 500 \mu \mathrm{L}$ of the supernatant was transferred into a $2 \mathrm{~mL}$ Eppendorff tube The supernatant was decanted and $500 \mu \mathrm{L}$ of phenol/chloroform/isoamylalcohol $(25: 24: 1, \mathrm{v} / \mathrm{v} / \mathrm{v})$ was added,. After vortexing for $30 \mathrm{~s}$, the mixture was centrifuged at $10,000 \mathrm{~g}$ for $5 \mathrm{~min}$. $600 \mu \mathrm{L}$ of the aqueous phase was transferred into a new 2 
$\mathrm{mL}$ Eppendorff tube containing $600 \mu \mathrm{L}$ chloroform/isoamylalcohol (24:1, v/v) and carefully mixed. After incubating the mixture at room temperature for at least 5 min a further centrifugation step was carried out $(10,000 \mathrm{~g}$, $10 \mathrm{~min}$ ). $400 \mu \mathrm{L}$ of the aqueous phase was transferred into a new $1.5 \mathrm{~mL}$ Eppendorff tube that already contained $320 \mu \mathrm{L}$ of isopropanol. The mixture was carefully mixed and incubated in the freezer at $-20{ }^{\circ} \mathrm{C}$ for at least $1 \mathrm{~h}$. After centrifugation at $10,000 \mathrm{~g}$ for $10 \mathrm{~min}$, the supernatant was decanted. The precipitated nucleic acid was washed with $500 \mu \mathrm{L}$ of $70 \%(\mathrm{v} / \mathrm{v})$ ethanol and centrifuged at $21000 \mathrm{~g}$ for $5 \mathrm{~min}$. The nucleic acid was resuspended in $100 \mu \mathrm{L} 0.1 \times \mathrm{TE}$ buffer $(10 \mathrm{mM}$ Tris $\mathrm{HCl}, 1 \mathrm{mM}$ EDTA; pH 8.0).

The extractions were performed in duplicate for each sample and binary mixtures. All extractions included a blank extraction for the control of reagents and contaminations during extraction procedure.

\section{DNA quantification and purity}

The concentration and the quality of the extracted DNA were determined by measuring its absorbance at 260 $\mathrm{nm}\left(\boldsymbol{A}_{260}\right)$ and $280 \mathrm{~nm}\left(\boldsymbol{A}_{280}\right)$ with a spectrophotometer (DS-11 Spectrophotometer DeNovix). The DNA concentration was calculated according to the following equation: $\mathrm{c}[\mathrm{ng} / \mu \mathrm{L}]=\boldsymbol{A}_{260} \times 50 \times$ dilution factor. The ratio $\boldsymbol{A}_{260} / \boldsymbol{A}_{280}$ was used to assess the purity of the extracted DNA. The DNA extracts were stored at $-20^{\circ} \mathrm{C}$.

\section{Oligonucleotide primers/probe}

The oligonucleotide primers and probes used in this work are presented in Table 1. The primers were synthetised by Life Technologies (Shanghai).

TABLE I. OLIGONUCLEOTIDE PRIMERS AND PROBES USED IN THE PCR AMPLIfiCATIONS TARGETING THE CYTB AND THE 12S RRNA GENES.

\begin{tabular}{|c|c|c|c|}
\hline $\begin{array}{l}\text { Target } \\
\text { gene }\end{array}$ & Primer/probe & Sequence(5'-3') & Reference \\
\hline \multirow{2}{*}{ Cytb } & Sheep $(F)$ & $\begin{array}{c}\text { ACA CAA CTT CTA CCA } \\
\text { CAA CCC }\end{array}$ & \multirow{3}{*}{ [11] } \\
\hline & Sheep(R) & $\begin{array}{c}\text { AAA CAA TGA GGG TAA } \\
\text { CGA GGG } \\
\text { (FAM)-ACA CCG AAA CAA }\end{array}$ & \\
\hline \multirow{4}{*}{$\begin{array}{l}12 \mathrm{~S} \\
\text { rRNA }\end{array}$} & CytbP & $\begin{array}{c}\text { AAT ACT CCT TGA GAA } \\
\text { ACA-(TAMRA) }\end{array}$ & \\
\hline & $12 \mathrm{~S}(\mathrm{~F})$ & $\begin{array}{c}\text { CAA ACT GGG ATT AGA } \\
\text { TAC CCC ACT A }\end{array}$ & \multirow{3}{*}{ [12] } \\
\hline & $12 \mathrm{~S}(\mathrm{R})$ & $\begin{array}{c}\text { ATC GRT TMT AGA ACA } \\
\text { GGC TCC TCT AG } \\
\text { (VIC)-CAC CGC CAA GTC }\end{array}$ & \\
\hline & $12 \mathrm{SP}$ & $\begin{array}{l}\text { CTT TGR GTT TTA RGC- } \\
\text { (none) }\end{array}$ & \\
\hline
\end{tabular}

\section{E. Real-time PCR analysis}

Real-time PCR reactions were carried out in a total volume of $15 \mu \mathrm{l}$ in strip tubes or in 96 well plates, depending on the ABI 7500 Fast Real-time PCR System (Applied Biosystems), using the following conditions: $95^{\circ} \mathrm{C}$ for $30 \mathrm{~s}, 40$ cycles at $95^{\circ} \mathrm{C}$ for $5 \mathrm{~s}$ and $60^{\circ} \mathrm{C}$ for $34 \mathrm{~s}$, with collection of fluorescence signal at the end of each cycle. Data were collected and processed using the 7500 Fast System Software V1.4.2. To develop a robust quantitative method that can be applied to processed meat products, the construction of a normalized calibration curve was proposed using the real-time PCR cycle threshold $(\mathrm{Ct})$ values from the amplification of the binary reference mixtures targeting Cytb and the endogenous control (12S rRNA). For that system, the application of $\Delta \mathrm{Ct}$ method to construct a calibration model was used by calculating: $\Delta \mathrm{Ct}=\mathrm{Ct}_{\mathrm{Cytb}}-\mathrm{Ct}_{12 \mathrm{~s} \text { rRA }}$

where $\mathrm{Ct}_{\text {cytb }}$ and $\mathrm{Ct}_{12 \text { srRNA }}$ are the cycle thresholds for soybean and eukaryotic systems, respectively. The calibration curve was then obtained by plotting the calculated $\Delta \mathrm{Ct}$ vs. the logarithm of sheep percentage of five concentration levels.

\section{F. Amplification efficiency(E)}

The amplification efficiency of the real-time PCR assay was determined by analyzing 4 DNA extracts from sheep that had been diluted serially (1:10 to $1: 100000)$. The final concentration of sheep DNA ranged from 50.75 $\mathrm{ng} / \mu \mathrm{L}$ to $5.075 \mathrm{pg} / \mu \mathrm{L}$. The amplification efficiency (E) was calculated from the slope of the standard curve: $\mathrm{E}[\%]$ $=[10(-1 /($ slope $))-1] \times 100$.

\section{G. Limit of detection (LOD)}

The limit of detection (LOD) of the real-time PCR assay was determined according to the European Network of GMO Laboratories guidelines. The DNA was isolated from a model meat mixture containing 20\% (w/w) sheep in pork. After adjusting the concentration to $50 \mathrm{ng} / \mu \mathrm{L}$ the DNA extract was diluted 1:5, 1:25 and 1:125. Each of the diluted extracts was analyzed in 10 replicates. The LOD was defined as the lowest concentration that yielded an increase of the fluorescence signal within 37 cycles in at least 9 out of 10 replicate measurements.

\section{RESULTS AND DISCUSSION}

\section{A. Amplification efficiency}

For calirbration, the amplification efficiency of DNA extracts from sheep were analyzed by both real-time PCR assay, the Cytb gene and the reference gene (12S rRNA). The concentration of sheep DNA was in the range from $50.75 \mathrm{ng} / \mu \mathrm{L}$ to $5.075 \mathrm{pg} / \mu \mathrm{L}$. The amplification curves and the standard curve obtained by plotting the $\mathrm{Ct}$ value against the logarithm of the DNA concentration are shown in Fig. 1A and Fig. 1B, respectively. For Cytb, a linear relationship $\left(\mathrm{R}^{2}=0.9958\right)$, the slope of the calibration curve was -3.2861 , corresponding to an amplification efficiency of $101.5 \%$. while for $12 \mathrm{~S}$ rRNA, showed the similar dynamic equation: a linear relationship $\left(\mathrm{R}^{2}=0.9997\right)$, the slope of the calibration curve was3.3093 , corresponding to an amplification efficiency of $100.5 \%$. 

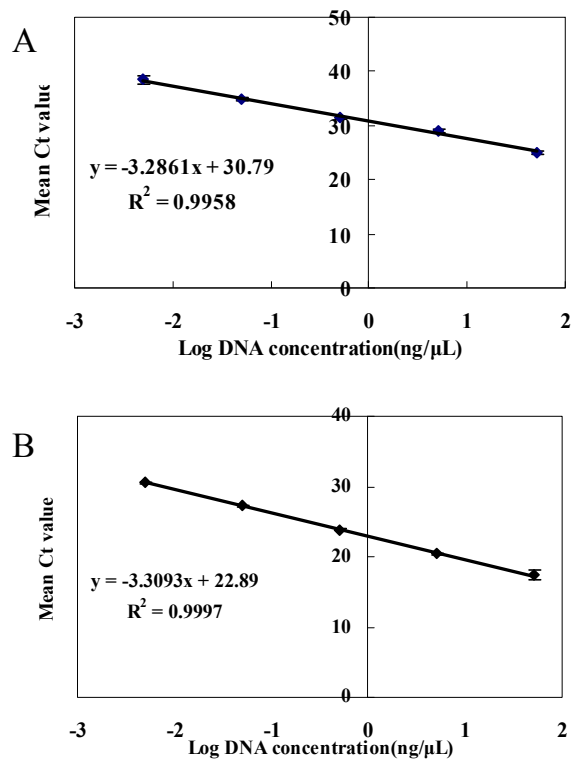

Figure 1. The amplification efficiency of the target gene (Cytb) and the endogenous control (12srRNA) .a.cyctb; b.12SrRNA

\section{B. Real-time PCR calibration curve and linearity}

The normalised calibration curve obtained by plotting the calculated $\Delta \mathrm{Ct}$ vs. the logarithm of sheep percentage of five concentration levels is presented in Fig. 2. Therefore, the estimation of sheep was determined by the equation:

Sheep $\%=10^{\frac{1.3077-\Delta C t}{4.0057}}$

This approach allows the estimation of added sheep meat at concentrations of $20 \%$ to $100 \%$ with a high correlation coefficient $\left(\mathrm{R}^{2}=0.994\right)$. The calculation of PCR efficiency is of major relevance to assess the performance of real-time quantitative PCR assays, being calculated from the slope of the calibration curve using the following expression: $\mathrm{E} \%=\left[10^{(-1 \text { (slope) })}-1\right] \times 100$.

The calculated value shows that a considerably high PCR efficiency was achieved for the normalised calibration curve $(77 \%)$ which is particularly important for a robust and precise quantitative PCR assasy ${ }^{[13]}$.

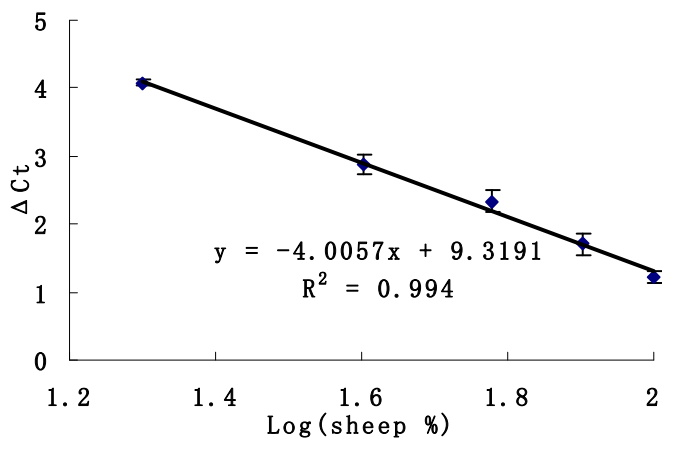

Figure 2. Normalised calibration curve for the estimation of the sheep meat in sheep-pork meat by real-time PCR, using eukaryotic amplification as a reference gene and the $\Delta \mathrm{Ct}$ method (mean values of independent assays and the bars are the standard deviations, $n=4)$.

\section{Limit of detection}

The LOD of the real-time PCR assay were determined by analyzing serially diluted DNA extracts from a model meat mixture containing $4 \%(\mathrm{w} / \mathrm{w})$ sheep in pork. The concentration of sheep obtained ranged from $4 \%(\mathrm{w} / \mathrm{w})$ to $0.16 \%(\mathrm{w} / \mathrm{w})$. The $\mathrm{Ct}$ values are summarized in Table 2 . The LOD, defined as the lowest concentration that resulted in an increase of the fluorescence signal within 37 cycles in at least 9 out of 10 replicates, was found to be $0.8 \%$ sheep. The limit of 37 cycles is set in routine analysis in the AGES in order to lower the probability of obtaining false positive signals, e.g. due to cross-reactivity.

TABLE II. DETERMINATION OF LOD WITH A SERIALLY DILUTED DNA EXTRACT FROM A MODEL MEAT MIXTURE CONTAINING 4\%SHEEP IN PORK

\begin{tabular}{ccccc}
\hline $\begin{array}{c}\text { content of } \\
\text { sheep(\%) }\end{array}$ & \multicolumn{2}{c}{ Ct value } & $\begin{array}{c}\text { Mean } \\
\text { Ct Value }\end{array}$ & std \\
\hline & 32.85 & 32.17 & & \\
4 & 32.30 & 32.36 & & 0.60 \\
& 32.53 & 32.73 & 32.71 & \\
& 32.30 & 33.73 & & \\
& 32.32 & 33.83 & & \\
0.8 & 34.86 & 35.98 & & \\
& 34.89 & 35.87 & & 0.62 \\
& 34.67 & 37.05 & 35.64 & \\
\hline & 34.76 & 36.16 & & \\
\hline & 35.13 & 36.88 & & \\
& 37.65 & 37.58 & & \\
& 37.74 & 37.37 & & \\
& 38.14 & 37.32 & 37.93 & \\
& 38.02 & 38.57 & & \\
& 37.61 & 39.26 & & \\
\hline
\end{tabular}

\section{In-house assay validation}

To validate the proposed real-time PCR methodology, binary mixtures prepared with known amounts of sheep in sheep-pork meat mixtures were analysed as blind samples. The respective $\mathrm{Ct}$ values for sheep and endogenous control of amplified blind mixtures were used to calculate $\Delta \mathrm{Ct}$ and estimate the amount of sheep based on the proposed standard calibration curve presented in Fig. 2. Table 3 shows the predicted and actual values of sheep meat percentage for the validation mixtures of 79.89 , $48.32,31.74$ and $21.30 \%$.

The close agreement between the average values obtained for the tested concentrations is evidenced by the high proximity between true and predicted values. The low coefficients of variation, from $0.11 \%$ to $0.38 \%$ in the range of tested concentrations, evidence the high repeatability of the technique. This is indicated by the low standard errors, demonstrating the trueness of the proposed technique for estimating the level of addition of sheep in meat products in the range $20-100 \%$.

TABLE III. RESULTS FOR THE VALIDATION OF THE REAL-TIME PCR QUANTITATIVE ASSAY.

\begin{tabular}{cccccc}
\hline \multirow{2}{*}{ Samples } & \multicolumn{2}{c}{ Sheep meat (\%) } & \multirow{2}{*}{ SD } & \multirow{2}{*}{ CV(\%) } & \multirow{2}{*}{ Error } \\
\cline { 2 - 5 } & Actual & Mean predicated & & & \\
\hline A & $79.89 \%$ & $72.79 \%$ & 0.0920 & 0.13 & -0.0888 \\
B & $48.32 \%$ & $46.46 \%$ & 0.0506 & 0.11 & -0.0385 \\
C & $31.74 \%$ & $32.37 \%$ & 0.1028 & 0.32 & 0.0198 \\
D & $21.30 \%$ & $19.93 \%$ & 0.0767 & 0.38 & -0.0642 \\
\hline SD-standard deviation & & & & \\
CV—coefficient of variation \\
Error-(mean value-true value) \\
Values are the mean of independentassays $(n=4)$
\end{tabular}




\section{CONCLUSION}

In the present work, we propose a real-time PCR method based on the use of specific TaqMan probes that proved to be a powerful tool, highly specific, sensitive and accurate for sheep detection and quantification in pork meat product. The method was successfully in-house validated, as evidenced by the low standard errors and high repeatability obtained in the analysis of blind mixtures.

In conclusion, this work highlights the importance of inspection programmes in the sector of meat products avoiding fraudulent practices and protecting the health of allergic consumers. Thus, the relevance of the proposed methodology was demonstrated as a useful tool for authentication/control, allowing the specific detection and quantification of sheep in meat products.

\section{ACKNOWLEDGMENT}

This work was supported by the Shanghai Municipal Bureau of Quality and Technical Supervision under Grant Nos. 2014-13.

\section{REFERENCES}

[1] Ali, M. E., Hashim, U., Mustafa, S., Che Man, Y. B., \& Islam, Kh. N (2012). Gold nanoparticle sensor for the visual detection of pork adulteration in meatball formulation. Journal of Nanomaterials, 2012, vol. 2012, Article ID 103607, 7 pages, 2012. doi:10.1155/2012/103607

[2] Ali, M. E., Hashim, U., Mustafa, S., Che Man, Y. B., Yusop, M. H. M., Bari, M. F., et al. (2011). Nanoparticle sensor for label free detection of swine DNA in mixed biological samples. Nanotechnology, 22, 195503.

[3] Nurjuliana, M., Che Man, Y. B., Mat Hashim, D., \& Mohamed, A. K. S. (2011). Rapid identification of pork for halal authentication using the electronic nose and gas chromatography mass spectrometer with headspace analyzer. Meat Science, 88(4), 638644.

[4] Toorop, R. M., Murch, S. J., \& Ball, R. O. (1997). Development of a rapid and accurate method for separation and quantification of myofibrillar proteins in meat. Food Research International, 30, 619-627.

[5] Asensio, L., González, I., García, T., \& Martín, R. (2008). Determination of food authenticity by enzyme-linked immunosorbent assay (ELISA). Food Control, 19, 1-8

[6] Rahman, A., Sismindary, Erwanto, Y., \& Che Man, Y. B. (2011) Analysis of pork adulteration in beef meatball using Fourier transform infrared (FTIR) spectroscopy. Meat Science, 88, 91-95.

[7] Farrokhi, R., \& Jafari Joozani, R. (2011). Identification of pork genome in commercial meat extracts for Halal authentication by SYBR green I real-time PCR. International Journal of Food Science and Technology, 46(5), 951-955.

[8] Köppel, R., Ruf, J., \& Rentsch, J. (2011). Multiplex real-time PCR for the detection and quantification of DNA from beef, pork, horse and sheep. European Food Research and Technology, 232(1), 151155.

[9] Sakai, Y., Kotoura, S., Yano, T., Kurihara, T., Uchida, K., Miake, K., et al. (2011). Quantification of pork, chicken and beef by using a novel reference molecule. Bioscience, Biotechnology, and Biochemistry, 75(9), 1639-1643.

[10] Development and validation of a TaqMan real-time PCR assay for the identification and quantification of roe deer (Capreolus capreolus) in food to detect food adulteration. Food Chemistry 178 (2015) 319-326

[11] Protocol of identification of bovine, caprine,ovine and porcine dervied materials in gelatin-Real time PCR method

[12]Zhang QP, Gu WJ, Qu QF, Hu XL, Yu Y, Chen XQ (2011). Identifi cation of Animal Derived Material in Vegetarian Foods. The Food Industry 32(10),112-115.

[13] Bustin, S. A., Benes, V., Garson, J. A., Hellemans, J., Huggett, J., Kubista, M., Mueller, R., Nolan, T., Pfaffl, M. W., Shipley, G. L., Vandesompele, J., \& Wittwer, C. T. (2009). The MIQE guidelines: Minimum information for publication of quantitative real-time PCR experiments. Clinical Chemistry, 55, 611-622. 